\title{
MLH3 Gene
}

National Cancer Institute

\section{Source}

National Cancer Institute. MLH3 Gene. NCI Thesaurus. Code C20210.

This gene plays a role in DNA mismatch repair and is associated with hereditary nonpolyposis colon cancer. 